\title{
Trend Analyses of Parameters of Equations for Minimum Fairness Proportion Achievable in Ubicomp MANETs Using Location-Aware Transmission.
}

\author{
M. Kaleem GALAMALI, Assoc. Prof Nawaz MOHAMUDALLY
}

\begin{abstract}
Managing energy consumption in ubicomp remains a significant topic of research. To assist in this issue, MANET transmission may be prone to future successes [74]. Despite all development of strategies for energy containment in MANETs, including application of location-aware transmission, it is still true that the software engineering notion of modelling in ubicomp is in its embryonic phases. Energy management is crucial because of constrained battery power of ubicomp nodes and its cost implications. A prior study was carried out [23] to quantify and model the Minimum Fairness Proportion (Min_FP) recordable for CBRs for node densities of 7 until 56. The corresponding model was perceived to be the decreasing exponential model.
\end{abstract}

In this paper, the next level of investigation is set forth as: "What are the trends of variation observable within each parameter of the equation of curve obtained for metric Min_FP [23] over varying node densities?"

Studying the behaviour of components of applicable models for metric Min_FP and successively model the observed pattern for each component mathematically is a commendable task since it will involve lots of effort and especially tough disagreement resolution among researchers. The results put forward will assist ubicomp specialists in better understanding MANET features and prepare algorithmic support for energy management in ubicomp architectures. Specially adapted battery design and hardware surrogates may also follow. This paper is a follow-up of previous work [1-38].

Key terms: Ubicomp- Ubiquitous Computing, MAUCMobile and Ubiquitous Computing, MANET- Mobile Adhoc Network, CBR- Constant Bit Rate, Min_FPMinimum Fairness Proportion.

M. Kaleem GALAMALI,

University of Technology Mauritius (student) Mauritius

Assoc. Prof Nawaz Mohamudally University of Technology Mauritius, Mauritius

\section{Introduction}

Ubicomp environments may suffer from poorly equipped networking devices and hence MANETs remain a hopeful solution for future ubicomp environments. Energy consumption load is repartitioned among cooperative nodes in ubicomp. Following this type of arising collective operation, the criteria of Fairness must be well comprehended. Fairness may be viewed from several angles or metrics value. One such viewpoint was studied previously [23], whereby the behaviour of metric Min_FP was elicited. The trend followed in that paper was the decreasing exponential equation of form:

$G(x)=a * \exp (b *(x-0.1))+c$

Here, the equation of the model has involved 3 parameters: $a, b$ and $c$. The next study required for metric Min_FP is the formulation of model equations for the parameters of the equation mentioned above.

The key contributions of this paper is the development of the trend of variation for each parameter of the equations involved in the model for metric Min_FP presented in a preceding paper [23], whose table 1 is referred to in this paper also. The mathematical procedures extended here may be inserted as an algorithm into software simulators, thus providing a utility for designers to more fruitfully study the progression and predictability of ubicomp characteristics and hence progress future ubicomp architecture. The rest of this paper is organised as follows: section 2- Parameter Trend Analysis- Metric Min_FP, section 3-Conclusion and References.

\section{Parameter Trend Analysis -}

\section{Metric Min_FP.}

\subsection{General Procedure Adopted.}

The first step is to plot the tabulated data for each parameter of the equations for the model for Min_FP on gnuplot. The second step is to accomplish graphical analyses and report general observations. The third step is to explore the applicability of some selected equations of fit. Choice of best fit is made considering values of least reduced chi-square and most commendable extendability produced at node numbers 80 and 100. The fourth step is to record the values of parameters for each Min_FP parameter of equation.

\subsection{Trend Analysis - Min FP parameter " $a$ ".}

Generally the curve shows increasing tendency at slowly decreasing rate. The curve does not tend 
towards flattening enough to depict logarithmic trend. A slight oscillation is also noticed but is not consistent throughout and hence has been neglected.

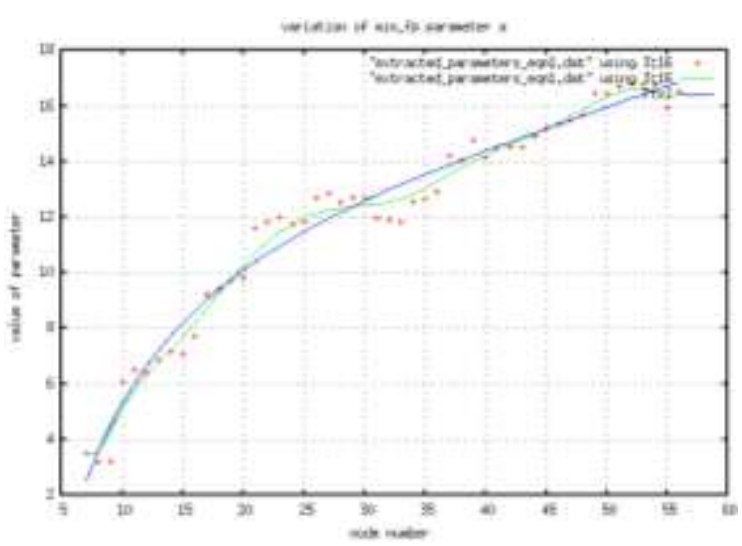

Figure 1: Min_FP parameter a

The potentially applicable equations of trend are:

1. $F(x)=a * x * \exp (b * x)+c * x^{0.5}$

$$
\text { Ch_sq }=0.613726 \quad \mathrm{~F}(80)=16.3655
$$

$\mathrm{F}(100)=15.120598$

2. $F(x)=a * x * \exp \left(b * x^{0.5}\right)+c * x^{0.5}$

Ch_sq $=0.560912 \quad \mathrm{~F}(80)=16.97422$

$\mathrm{F}(100)=16.351227$

3. $F(x)=a * x \star \exp \left(b * x^{0.5}\right)+c * x^{0.5}+d$

Ch_sq $=0.460783 \quad \mathrm{~F}(80)=20.3494$

$\mathrm{F}(100)=23.23$

\section{Choice of best fit for Min_FP parameter a}

The equation in part 3 above has been selected because of both smallest reduced chi-square value obtained and good extendability. The parameters for best fit are: $\mathrm{a}=5.71416, \mathrm{~b}=-0.536204, \mathrm{c}=3.77133, \mathrm{~d}=$ 17.1597

\subsection{Trend Analysis - Min_FP parameter " $b$ ".}

Generally the curve shows decreasing tendency at a slowly decreasing rate. Again, a non-uniform oscillation is noticed but is more complicated to accommodate and is hence neglected.

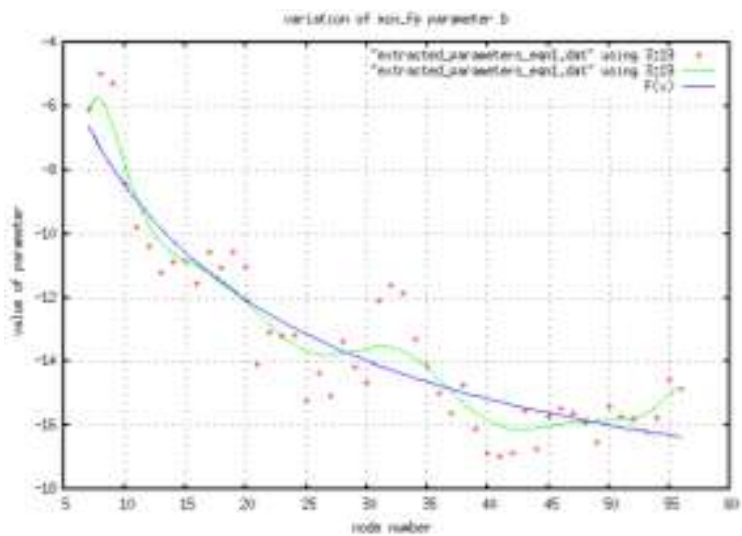

Figure 2: Min_FP parameter b

The potentially applicable equations of trend are:

$$
\begin{array}{r}
\text { 1. } F(x)=(a * x) / \log ((b * x)+c) \\
\text { Ch_sq }=1.52595 \\
\text { 2. } F(x)=\left(a * x^{1.5}\right) / \log ((b * x)+c) \\
\text { Ch_sq }=1.40856 \quad F(100)=-12 . . . .
\end{array}
$$

Note: curve increases drastically after some time

3. $F(x)=(a * x) / \log ((b * x)+c)+d$

$$
\begin{array}{ll}
\text { Ch_sq }=1.52217 & F(80)=-17.39667 \\
F(100)=-17.931414 &
\end{array}
$$

\section{Choice of best fit for Min_FP parameter b}

The equation in part 3 above has been selected because it has better extendability feature even if the ch_sq value is not smallest. The parameters for best fit are:

$a=-0.00308434, b=0.000146133, c=1.00181, d=1$

\subsection{Trend Analysis - Min FP parameter "c".}

Generally the curve depicts a general increasing tendency despite the scattered plots. Here also, an inconsistent non-uniform and small oscillation is visible but is neglected since the $y$-axis intervals are already very small.

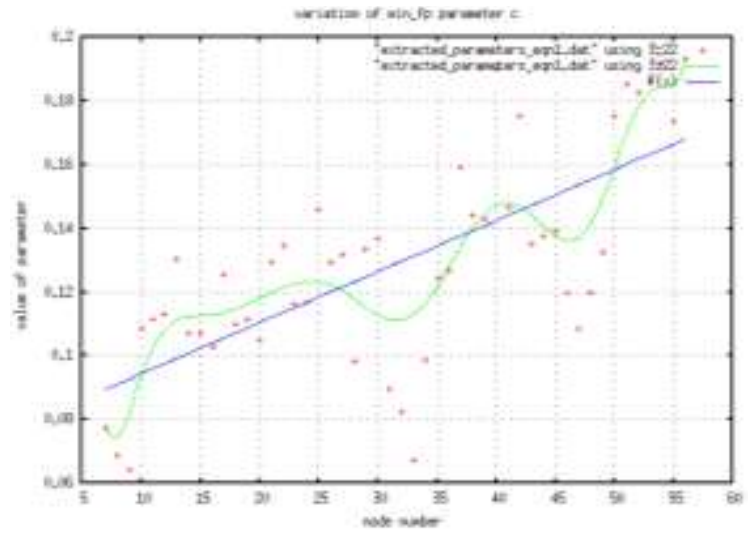

Figure 3: Min_FP parameter c

The applicable equation here is

$$
\begin{aligned}
& F(x)=d * x+f \\
& \text { Ch_sq }=0.000572429 \quad F(80)=0.206619 \\
& F(100)=0.238696959
\end{aligned}
$$

The parameters for best fit are: $d=0.00160388, f=0.0783086$

\section{Conclusion.}

This investigation was targeted at and has achieved the establishment of applicable models of trends of the parameters of equations for the metric Min_FP in a MANET topography of $300 \times 300 \mathrm{~m}^{2}$. These models, illustrated as mathematical equations of varying complexity levels, will enable further study of MANETs for MAUC environments from a software engineering approach. Such development may then help in formulating computational algorithms to be fed 
into simulators for further studies of MANETs. This experiment was undertaken in NS-2 over linux. The plottings and "fit" attempts were conducted in gnuplot. Criteria for selecting best fit have been reduced chisquare values and best extendability of equations attained.

The credible assumptions mentioned in previous paper [23] are carried forward in this paper too. Gnuplot is justly assumed as sutiable for the scope of this study.

Further work identified remain: formulating methods of predictability for metric Min_FP and its trend and reporting observations of certain critical values identified.

\section{References}

[1] M. Kaleem GALAMALI, Assoc. Prof Nawaz MOHAMUDALLY, Towards Dependable Pervasive Systems-A Position and Vision Paper, CEET 2014

[2] M. Kaleem GALAMALI, Assoc. Prof Nawaz MOHAMUDALLY, Model of Energy Savings achievable with Location-aware Node-to-Node Transmission in UbiComp , CEET 2014

[3] M. Kaleem GALAMALI, Assoc. Prof Nawaz MOHAMUDALLY, Model of Energy Savings achievable with Location-aware Node-to-Node Transmission in UbiComp Using Location Refresh Intervals, CEET 2014

[4] M. Kaleem GALAMALI, Assoc. Prof Nawaz MOHAMUDALLY, Model of Energy Savings achievable with Location-aware Transmission in UbiComp Using Relays, CEET 2014

[5] M. Kaleem GALAMALI, Assoc. Prof Nawaz MOHAMUDALLY, Mathematical modeling of need of exact number of relays to ensure seamless mobility in mobile computing, CEET 2014

[6] M. Kaleem GALAMALI, Assoc. Prof Nawaz MOHAMUDALLY, Modelling of need for multiple relays for ensuring seamless mobility, CEET 2014

[7] M. Kaleem GALAMALI, Assoc. Prof Nawaz MOHAMUDALLY, Investigation of prominence of placements of relays in a ubicomp topography,

[8] M. Kaleem GALAMALI, Assoc. Prof Nawaz MOHAMUDALLY, Model of energy savings achievable with location-aware transmission in ubicomp using optimised number of relays.

[9] M. Kaleem GALAMALI, Assoc. Prof Nawaz MOHAMUDALLY, Investigation of Prominence of Placements of Optimised Number of Relays in a Ubicomp Topography using Location-Aware Transmission, CEET 2015.

[10] M. Kaleem GALAMALI, Assoc. Prof Nawaz MOHAMUDALLY, Extending Node Battery Availability in Ubicomp with Location-Aware Transmission, CEET 2015.

[11] M. Kaleem GALAMALI, Assoc. Prof Nawaz MOHAMUDALLY, Extending Node Battery Availability in Ubicomp with Location-Aware Transmission using Location Refresh Intervals, CEET 2015.

[12] M. Kaleem GALAMALI, Assoc. Prof Nawaz MOHAMUDALLY, Extending Node Battery Availability in Ubicomp with Location-Aware Transmission using Uniformly Placed Relays, CEET 2015.

[13] M. Kaleem GALAMALI, Assoc. Prof Nawaz MOHAMUDALLY, Extending Node Battery Availability in Ubicomp with Location-Aware Transmission Using Optimally Placed Relays, CEET 2015.

[14] M. Kaleem GALAMALI, Assoc. Prof Nawaz
MOHAMUDALLY, Model of Sender Node Energy Savings Achievable with Location-Aware MANET Transmission in Ubicomp. ACCN 2016

[15] M. Kaleem GALAMALI, Assoc. Prof Nawaz MOHAMUDALLY, Model of Overall Node Energy Savings Achievable with Location-Aware MANET Transmission in Ubicomp. ACCN 2016

[16] M. Kaleem GALAMALI, Assoc. Prof Nawaz MOHAMUDALLY, Model of Sender Node Extra Energy Savings Achievable in MANET Against Direct Node-toNode Transmission Using Location-Aware Transmission in Ubicomp. ACCN 2016

[17] M. Kaleem GALAMALI, Assoc. Prof Nawaz MOHAMUDALLY, Model of Overall Node Extra Energy Savings Achievable in MANET against Direct Node-toNode Transmission Using Location-Aware Transmission in Ubicomp. ACCN 2016

[18] M. Kaleem GALAMALI, Assoc. Prof Nawaz MOHAMUDALLY, Model of Energy Consumption Ratio Achievable in MANET Using Location-Aware Transmission in Ubicomp. ACCN 2016

[19] M. Kaleem GALAMALI, Assoc. Prof Nawaz MOHAMUDALLY, Model of Minimum Energy Consumption Ratio Achievable in MANET Using LocationAware Transmission in Ubicomp. ACCN 2016

[20] M. Kaleem GALAMALI, Assoc. Prof Nawaz MOHAMUDALLY, Model of Maximum Energy Consumption Ratio Achievable in MANET Using LocationAware Transmission in Ubicomp. ACCN 2016

[21] M. Kaleem GALAMALI, Assoc. Prof Nawaz MOHAMUDALLY, Model of Overall Energy Consumption Fairness Ratio Achievable in MANET Using LocationAware Transmission in Ubicomp. ACCN 2016

[22] M. Kaleem GALAMALI, Assoc. Prof Nawaz MOHAMUDALLY, Model of Overall Energy Consumption Fairness Proportion Achievable in MANET Using LocationAware Transmission for Ubicomp, CEET 2016

[23] M. Kaleem GALAMALI, Assoc. Prof Nawaz MOHAMUDALLY, Model of Minimum Fairness Proportion Achievable in MANET Using Location-Aware Transmission for Ubicomp, CEET 2016

[24] M. Kaleem GALAMALI, Assoc. Prof Nawaz MOHAMUDALLY, Model of Maximum Fairness Proportion Achievable in MANET Using Location-Aware Transmission for Ubicomp, CEET 2016

[25] M. Kaleem GALAMALI, Assoc. Prof Nawaz MOHAMUDALLY, Model of Sender Fairness Proportion Achievable in MANET Using Location-Aware Transmission for Ubicomp, CEET 2016

[26] M. Kaleem GALAMALI, Assoc. Prof Nawaz MOHAMUDALLY, Model of Distance Travelled by packets in MANETs using Location-Aware Transmission for Ubicomp, CEET 2016

[27] M. Kaleem GALAMALI, Assoc. Prof Nawaz MOHAMUDALLY, Model of Maximum CBR Distance Travelled by packets in MANETs using Location-Aware Transmission for Ubicomp, CEET 2016

[28] M. Kaleem GALAMALI, Assoc. Prof Nawaz MOHAMUDALLY, Model of Minimum CBR Distance Travelled by packets in MANETs using Location-Aware Transmission for Ubicomp, CEET 2016

[29] M. Kaleem GALAMALI, Assoc. Prof Nawaz MOHAMUDALLY, Model of Range CBR Distance Experienced by Transmissions in MANETs using LocationAware Transmission for Ubicomp, CEET 2016

[30] M. Kaleem GALAMALI, Assoc. Prof Nawaz MOHAMUDALLY, Trend Analyses of Parameters of Equations for Sender Node Energy Savings Achievable in ubicomp MANETs using Location-Aware Transmission, ACCN 2017.

[31] M. Kaleem GALAMALI, Assoc. Prof Nawaz MOHAMUDALLY, Trend Analyses of Parameters of Equations for Overall Node Energy Savings Achievable in ubicomp MANETs using Location-Aware Transmission, ACCN 2017.

[32] M. Kaleem GALAMALI, Assoc. Prof Nawaz MOHAMUDALLY, Trend Analyses of Parameters of Equations for Sender Node Extra Energy Savings Achievable 
in MANET against Direct Node-to-Node Location-Aware Transmission, ACCN 2017.

[33] M. Kaleem GALAMALI, Assoc. Prof Nawaz MOHAMUDALLY, Trend Analyses of Parameters of Equations for Overall Nodes Extra Energy Savings Achievable in MANET against Direct Node-to-Node Location-Aware Transmission, ACCN 2017.

[34] M. Kaleem GALAMALI, Assoc. Prof Nawaz MOHAMUDALLY, Trend Analyses of Parameters of Equations for Energy Consumption Ratio Achievable in Ubicomp MANET Using Location-Aware Transmission, ACCN 2017.

[35] M. Kaleem GALAMALI, Assoc. Prof Nawaz MOHAMUDALLY, Trend Analyses of Parameters of Equations for Minimum Energy Consumption Ratio Achievable in Ubicomp MANETs Using Location-Aware Transmission, ACCN 2017.

[36] M. Kaleem GALAMALI, Assoc. Prof Nawaz MOHAMUDALLY, Trend Analyses of Parameters of Equations for Maximum Energy Consumption Ratio Achievable in Ubicomp MANETs Using Location-Aware Transmission, ACCN 2017.

[37] M. Kaleem GALAMALI, Assoc. Prof Nawaz MOHAMUDALLY, Trend Analyses of Parameters of Equations for Overall Fairness Ratio Achievable in Ubicomp MANETs Using Location-Aware Transmission, ACCN 2017.

[38] M. Kaleem GALAMALI, Assoc. Prof Nawaz MOHAMUDALLY, Trend Analyses of Parameters of Equations for Energy Consumption Fairness Proportion Achievable in Ubicomp MANETs Using Location-Aware Transmission, CEET 2017

[39] Markus Bylund and Zary Segall, Towards seamless mobility with personal servers, 2004

[40] Masugi Inoue, Mikio Hasegawa, Nobuo Ryoki and Hiroyuki Morikawa, Context-Based Seamless Network and Application Control, 2004

[41] Xiang Song, Umakishore Ramachandran, MobiGo: A Middleware for Seamless Mobility, College of Computing Georgia Institute of Technology, Atlanta, GA, USA, August 2007

[42] Budzisz, Ferrús, R., Brunstrom A., Grinnemo, K, Fracchia, R., Galante, G., and Casadevall, F. Towards transport-layer mobility: Evolution of SCTP multihoming, March 2008

[43] Paul Dourish \& Genevieve Bell, Divining a digital future, 2011.

[44] Xiang Song, Seamless Mobility In Ubiquitous Computing Environments, PhD Thesis, Georgia Institute of Technology, August 2008

[45] Kevin O Mahony, Jian Liang, Kieran Delaney, User-Centric Personalization and Autonomous Reconfiguration Across Ubiquitous Computing Environments, NIMBUS Centre Cork Institute of Technology, Cork, Ireland, UBICOMM 2012

[46] Pablo Vidales, Seamless mobility in 4G systems, Technical Report, University of Cambridge, Computer Laboratory, Number 656, November 2005

[47] João Pedro Sousa and David Garlan, Aura: An Architectural Framework for User Mobility in Ubiquitous Computing Environments, School of Computer Science, Carnegie Mellon University, USA, August 2002

[48] Dennis Lupiana, Ciaran O'Driscoll, Fredrick Mtenzi, Defining Smart Space in the Context of Ubiquitous Computing, Dublin Institute of Technology, Ireland, Special Issue on ICIT 2009 Conference - Web and Agent Systems, 2009

[49] N.S.V.Shet1, Prof.K.Chandrasekaran2 and Prof. K.C.Shet3, WAP Based Seamless Roaming In Urban Environment with Wise Handoff Technique, International Journal of UbiComp (IJU), Vol.1, No.4, October 2010

[50] Yipeng $\mathrm{Yu}$ Dan He Weidong Hua Shijian Li Yu Qi Yueming Wang Gang Pan, FlyingBuddy2: A Braincontrolled Assistant for the Handicapped, Zhejiang University, UbiComp'12, September 5-8, 2012

[51] Jing Su, James Scott, Pan Hui, Jon Crowcroft, Eyal de Lara Christophe Diot, Ashvin Goel, Meng How Lim, and Eben Upton, Haggle: Seamless Networking for Mobile Applications, 2007

[52] Rui Han, Moustafa M. Ghanem, Li Guo, Yike Guo*,
Michelle Osmond, Enabling cost-aware and adaptive elasticity of multi-tier cloud applications, Future Generation Computer Systems, 2012

[53] Byrav Ramamurthy, K. K. Ramakrishnan, Rakesh K. Sinha, Cost and Reliability Considerations in Designing the NextGeneration IP over WDM Backbone Networks, 2012.

[54] Bhavish Aggarwal, Aditya Akella, Ashok Anand, Athula Balachandran, Pushkar Chitnis, Chitra Muthukrishnan, Ram Ramjee and George Varghese, EndRE: An End-System Redundancy Elimination Service for Enterprises, NSDI 2010, San Jose, CA

[55] Ashok Anand, Vyas Sekar and Aditya Akella, SmartRE: An Architecture for Coordinated Network-wide Redundancy Elimination, SIGCOMM 2009, Barcelona, Spain

[56] John Breeden II, "Smart-phone battery life could double without better batteries", Nov 14, 2012

[57] Andy Boxall, "When will your phone battery last as long as your kindle", December 5, 2012

[58] Imielinski, T. and Navas, J.C. (1999). GPS-based geographic addressing, routing, and resource discovery. Comms. ACM, Vol. 42, No. 4, pp. 86-92.

[59] Hightower, J. and Borriello, G. (2001). Location Systems for Ubiquitous Computing. IEEE Computer, Vol. 34, No. 8 August, pp. 57-66.

[60] Harter, A., Hopper, A., Steggles, P., Ward, A. and Webster, P. (2002). The Anatomy of a Context-Aware Application. Wireless Networks, Vol. 8, No. 2-3, Mar-May, pp. 187-197.

[61] Hightower, J., Brumitt, B. and Borriello, G. (2002). The Location Stack: A Layered Model for Location in Ubiquitous Computing. Proceedings of the 4th IEEE Workshop on Mobile Computing Systems \& Applications (WMCSA 2002), Callicoon, NY, USA, June, pp. 22-28.

[62] Graumann, D., Lara, W., Hightower, J. and Borriello, G. (2003). Real-world implementation of the Location Stack: The Universal Location Framework. Proceedings of the 5th IEEE Workshop on Mobile Computing Systems \& Applications (WMCSA 2003), Monterey, CA, USA, October, pp. $122-128$

[63] Ko, Y., \& Vaidya, N. H. (2000). Location-aided routing (LAR) in mobile ad hoc networks. Wireless Networks, 6(4), 307-321.

[64] Liao, W.-H., Tseng, Y.-C., \& Sheu, J.-P. (2001). GRID: a fully location-aware routing protocol for mobile ad hoc networks. Telecommunication Systems, 18(1), 37-60.

[65] Kuhn, F., Wattenhofer, R., Zhang, Y., \& Zollinger, A. (2003). Geometric ad-hoc routing: of theory and practice. In Proceedings of the ACM (PODC'03) (pp. 63-72).

[66] Jiang, X., \& Camp, T. (2002). Review of geocasting protocols for a mobile ad hoc network. In Proceedings of the Grace Hopper Celebration (GHC).

[67] Ko, Y. \& Vaidya, N. H. (1999). Geocasting in mobile ad hoc networks: location-based multicast algorithms. In Proceedings of the IEEE (WMCSA'99) (pp. 101).

[68] Mauve, M., Fuler, H., Widmer, J., \& Lang, T. (2003) Position-based multicast routing for mobile ad-hoc networks (Technical Report TR-03-004). Department of Computer Science, University of Mannheim.

[69] Xu, Y., Heidemann, J., \& Estrin, D. (2001). Geographyinformed energy conservation for adhoc routing. In Proceedings of the ACM/IEEE (MOBICOM'01) (pp. 70-84).

[70] Hu, Y.-C., Perrig, A., \& Johnson, D. (2003). Packet leashes: a defense against wormhole attacks in wireless ad hoc networks. In Proceedings of the INFOCOM' 03 (pp. 19761986)

[71] Patwari, N., Hero III, A. O., Perkins, M., Correal, N. S., \& O’Dea, R. J. (2003). Relative location estimation in wireless sensor networks. IEEE Transactions on Signal Processing, 51(8), 2137-2148.

[72] Baldauf, M., Dustdar, S., \& Rosenberg, F. (2007). A Survey on Context Aware Systems. International Journal of Ad Hoc 
and Ubiquitous Computing, Inderscience Publishers. forthcoming. Pre-print from: http://www.vitalab.tuwien.ac.at/ florian/papers/ijahuc2007.pdf

[73] Hong, D., Chiu, D.K.W., \& Shen, V.Y. (2005). Requirements elicitation for the design of context-aware applications in a ubiquitous environment. In Proceedings of ICEC'05 (pp. 590-596).

[74] Neeraj Tantubay, Dinesh Ratan Gautam and Mukesh Kumar Dhariwal, A Review of Power Conservation in Wireless Mobile Ad hoc Network (MANET)", International Journal of computer Science Issues, Vol 8, Issue 4, No 1, July 2011.

[75] Wenrui Zhao, Mostafa Ammar and Ellen Zegura, "A

Message Ferrying Approach for Data Delivery in Sparse Mobile Ad Hoc Networks", MobiHoc'04, May 24-26, 2004, Roppongi, Japan.

About Author (s):

Associate Professor Nawaz Mohamudally works at University of Technology, Mauritius (UTM) and has undertaken supervision of MPhil/PhD Students for many years.

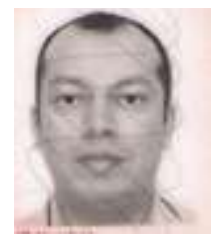

M. Kaleem Galamali is a part-time student (achieved M Phil Transfer on 28.10.2014, currently PhD student) at UTM under supervision of A.P. Nawaz Mohamudally. 